\title{
Explosion Cladding of Lead on Steel
}

\author{
Milan Turňa ${ }^{1}$, Jozef Ondruška $^{1}$, Zuzana Turňová ${ }^{1}$ \\ ${ }^{1}$ Slovak University of Technology, Faculty of Materials Science and Technology, J. Bottu 25, 917 24 Trnava, Slovakia \\ Correspondence to: milan.turna@stuba.sk
}

\begin{abstract}
This work deals with explosion cladding of lead on steel. The welded materials and the Semtex S type explosive are characterised. The preparation of the welded materials and the proposed welding assembly are described. The welding parameters, the welding conditions and the fabrication of the weld overlays are discussed. The quality of the fabricated bimetals was studied by optical and electron microscopy and by mechanical tests.
\end{abstract}

Keywords: lead, structural carbon steel, explosion cladding.

\section{Introduction}

As it is well known, fusion welding, soldering and thermal cutting of lead, including metals combined with lead, is at present prohibited in technical practice. In some cases, however, the use of lead is possible and/or unavoidable. Obvious examples are in the military and chemical industries. Bimetals of lead and other structural materials are interesting for the chemical industry. Bimetals such as $\mathrm{Pb}-$ structural carbon steel are attractive mainly owing to the high corrosion resistance of lead and the sufficient strength of steel. These bimetalsare used for fabricating vessels for storing dangerous materials, e.g. $\mathrm{H}_{2} \mathrm{SO}_{4} 90 \%, \mathrm{H}_{2} \mathrm{SO}_{4} 60 \%, \mathrm{PSCl}_{3} 95 \%, \mathrm{PCl}_{3}$, $\mathrm{NaNO}_{3}$. For storing aggressive media a lead layer on steel $3-5 \mathrm{~mm}$ in thickness is used depending on the corrosive medium. Until recently the interior of the chemical vessels was first tinned, and then a $\mathrm{Pb}$ layer was deposited on it. This procedure posed a great health risk for the persons performing the operations even resulting in occupational diseases. To avoid this kind of risk solid state surfacing, namely by explosion cladding, has been selected as a more suitable technology.

\section{Experimental}

The materials selected for our experiments were as follows: $99.95 \%$ lead by STN 423701 , and the steel type 11373 by STN 425340 , S235JRG1 by EN $10025 \mathrm{~A} 1$. Owing to its low melting point, lead is used with working temperatures only from 150 to $170{ }^{\circ} \mathrm{C}$. Only technically pure lead is used in the chemical industry as pure lead has the highest resistance against corrosion. The chemical resistance of lead in some environments may be increased by the addition of a small amount of $\mathrm{H}_{2} \mathrm{SO}_{4}$ to provide a protective layer on the material surface. So-called "hard lead" is not suitable for welding, since it causes embrittlement of welded joints. The chemical composition of the welded materials is shown in Tables 1 and 2 .

Table 1: Chemical composition of $\mathrm{Pb} 99.95$

\begin{tabular}{|c|c|c|c|c|c|c|c|c|}
\hline \multicolumn{10}{|c|}{$\mathrm{Pb} 99.95$ by STN $423701[$ wt.\%] } \\
\hline $\mathrm{Pb}$ & $\mathrm{Ag}$ & $\mathrm{Bi}$ & $\mathrm{Cu}$ & $\mathrm{Sb}$ & $\mathrm{As}$ & $\mathrm{Fe}$ & $\mathrm{Zn}$ & $\mathrm{Sn}$ \\
\hline min. & max. & max. & max. & max. & max. & max. & max. & max. \\
99.95 & 0.0015 & 0.030 & 0.0015 & 0.005 & 0.002 & 0.002 & 0.002 & 0.002 \\
\hline
\end{tabular}

Table 2: Chemical composition of steel type 11373

\begin{tabular}{|c|c|c|c|c|}
\hline \multicolumn{5}{|c|}{ Steel type 11373 by STN 425340 [wt.\%] } \\
\hline $\mathrm{C}$ & $\mathrm{N}$ & $\mathrm{P}$ & $\mathrm{S}$ & - \\
\hline $\max .0 .170$ & max. 0.007 & $\max .0 .045$ & $\max .0 .045$ & - \\
\hline
\end{tabular}


Table 3: Physical properties of lead

\begin{tabular}{|l|c|}
\hline \multicolumn{2}{|c|}{ Physical properties of $\mathrm{Pb} 99.95$} \\
\hline Density $\rho\left[\mathrm{kg} \cdot \mathrm{m}^{-3}\right]$ & 11341 \\
\hline Elasticity modulus in tension $E[\mathrm{MPa}]$ & $(14.71$ to 17.65$) \cdot 10^{-3}$ \\
\hline Elasticity modulus in shear $G[\mathrm{MPa}]$ & $6.865 \cdot 10^{-3}$ \\
\hline Sound propagation velocity $v\left[\mathrm{~m} \cdot \mathrm{s}^{-1}\right]$ & 1200 \\
\hline
\end{tabular}

Table 4: Mechanical properties of steel type 11373

\begin{tabular}{|l|c|}
\hline \multicolumn{2}{|l|}{ Selected mechanical properties of steel type 11373} \\
\hline Yield point Rp0.2 [MPa] & 225 \\
\hline Ultimate tensile strength Rm [MPa] & 363 to 441 \\
\hline Minimum ductility A5 [\%] & 25 \\
\hline
\end{tabular}

Table 5: Cladding parameters (charge thickness $H$, explosive density $\rho$, detonation velocity $v_{d}$, distance spacing $h$, setting angle of accelerated metal $\left[^{\circ}\right]$, deviation angle of accelerated metal $\left[{ }^{\circ}\right]$, collision velocity $v_{k}$, final velocity $v_{0}$ )

\begin{tabular}{|c|c|c|c|c|c|c|c|c|c|}
\hline No. & $\begin{array}{c}H \\
{[\mathrm{~mm}]}\end{array}$ & $\begin{array}{c}P \\
{\left[\mathrm{~g} \cdot \mathrm{cm}^{-3}\right]}\end{array}$ & $\begin{array}{c}v_{d} \\
{\left[\mathrm{~m} \cdot \mathrm{s}^{-1}\right]}\end{array}$ & $\begin{array}{c}h \\
{[\mathrm{~mm}]}\end{array}$ & $\begin{array}{c}\alpha \\
{\left[{ }^{\circ}\right]}\end{array}$ & $\begin{array}{c}\vartheta d \\
{\left[{ }^{\circ}\right]}\end{array}$ & $\begin{array}{c}v_{k} \\
{\left[\mathrm{~m} \cdot \mathrm{s}^{-1}\right]}\end{array}$ & $\begin{array}{c}V_{0} \\
{\left[\mathrm{~m} \cdot \mathrm{s}^{-1}\right]}\end{array}$ & $\begin{array}{c}\text { Expl. } \\
\text { type }\end{array}$ \\
\hline 1 & 31.6 & 0.980 & 1336 & $5.1-9.8$ & 2.23 & $8.6-8.9$ & $1060-1070$ & 207 & SP-14 \\
\hline 2 & 31.5 & 0.984 & 1340 & 7.5 & 0 & 8.8 & 1340 & 208 & SP-14 \\
\hline 3 & 50.8 & 1.090 & 1454 & 7.2 & 0 & 12.6 & 1454 & 343 & SP-14 \\
\hline 4 & 50.7 & 1.110 & 1474 & $7.0-13.1$ & 2.80 & $12.7-13.5$ & $1210-1230$ & 351 & SP-14 \\
\hline 5 & 51.7 & 1.030 & 1390 & $8.0-17.5$ & 4.35 & $12.5-13.1$ & $1040-1050$ & 320 & SP-14 \\
\hline 6 & 51.5 & 1.260 & 1250 & $8.0-17.5$ & 4.35 & - & - & - & SN-12 \\
\hline 7 & 51.8 & 1.250 & 1250 & $8.8-18.0$ & 4.26 & - & - & - & SN-12 \\
\hline 8 & 21.6 & 1.156 & 1990 & $4.9-22.7$ & 8.10 & $9.1-9.6$ & $1070-1080$ & 332 & S-25 \\
\hline
\end{tabular}
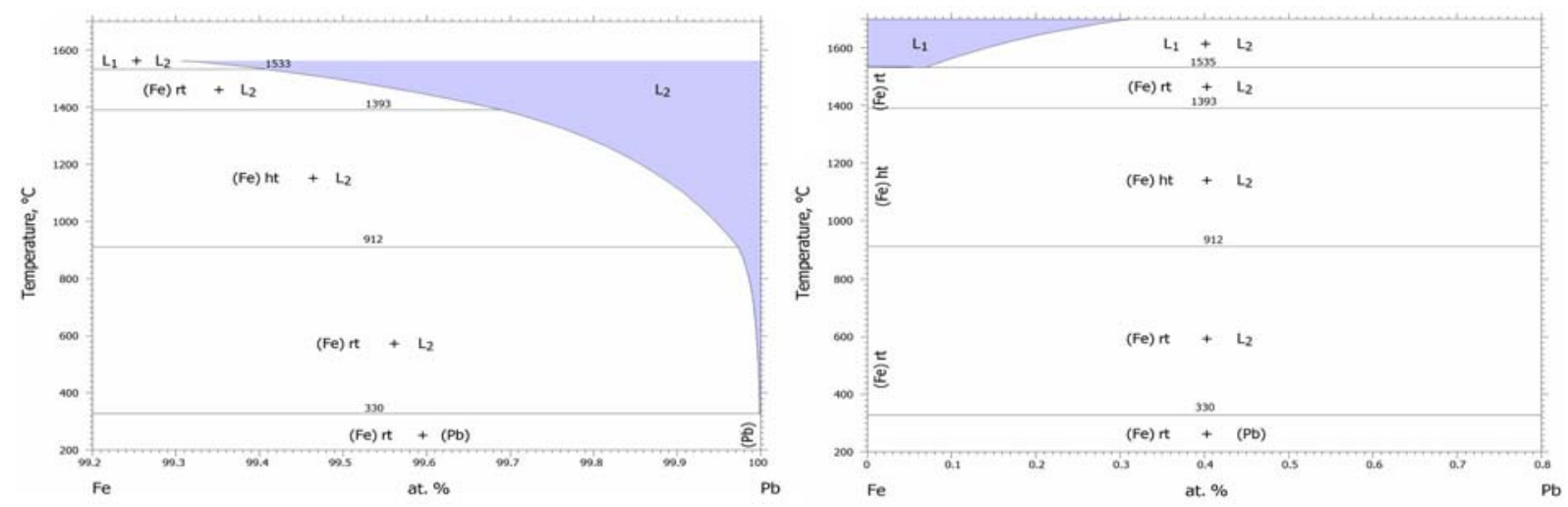

Figure 1: Parts of the $\mathrm{Fe}-\mathrm{Pb}$ binary diagram

The physical and mechanical properties of $\mathrm{Pb}$ and steel needed for the welding process are presented in Tables 3 and 4.

The parameters of the cladding process are given in Table 5.

Prior to welding, it was necessary to make a detailed study of the $\mathrm{Pb}$ - steel binary diagram, and to ascertain the possibility that undesired phases might be formed (Figure 1).

All materials to be explosion welded must be free from impurities and organic deposits, irrespective of the cleaning effect of cleaning agents. The weld surfaces on steel were machined by grinding to roughness $R_{a}=3.2 \mu \mathrm{m}$, and shortly before welding they 

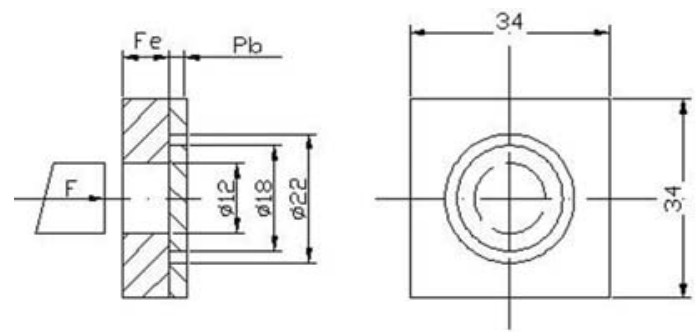

Figure 2: Scheme of the peel test

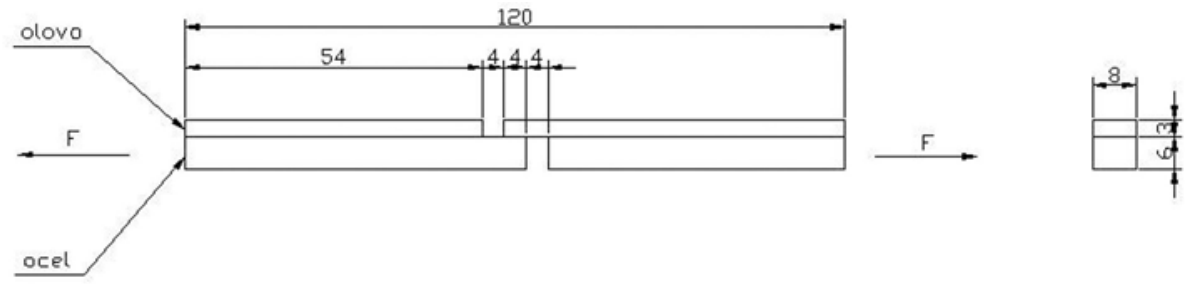

Figure 3: Shear test of the bimetal

were degreased with acetone. The lead was straightenedprior to welding, cleaned with a steel brush and degreased with acetone.

The welding parameters are given in Table 5 . The explosives for explosion welding do not form a unified group. They need to have specific properties for each technological process. To achieve good process reproducibility, the explosive that is used needs to have a stable detonation regime in non-sealed charges. Loose Semtex S type explosives were used for fabricating $\mathrm{Pb}$ - steel bimetals. These explosives were manufactured at RIICH Synthesia, Pardubice. After welding, the bimetals were cleaned from detonation products with a brush under running water and were then prepared for further study.

The following assessment methods were applied for our study of the quality of the fabricated bimetal joints: ultrasonic defectoscopy, mechanical tests, corrosion resistance tests and metallographic investigation.

\subsection{Ultrasonic defectoscopy}

The inspection was performed from the lead side. Probe coupling was ensured by the use of oil. The tests were performed usingthe USIP 11equipment with a MSEB $6 \mathrm{H}$ probe with $6 \mathrm{MHz}$ frequency. No defects were found in the joint boundary zone. The initial $3.2 \mathrm{~mm}$ thickness of the lead plate was reduced to 2.8 to $3.0 \mathrm{~mm}$ owing to the high detonation velocity and compression.

\section{$2.2 \quad$ Mechanical tests}

The quality of the fabricated joints was assessed by the following mechanical tests: a peel test, a shear strength test, and a bend test.

Peel test: an ordinary shop hydraulic press was used for this test. It must be stated that this test is not standardised and therefore it serves only to provide information on the boundary quality. The scheme of the test specimens is shown in Figure 2. The test showed that the boundary remained undamaged and the punch penetrated through the lead.

Shear strength test: three specimens with dimensions as shown in Figure 3 were cut from the bimetals in the direction of detonation wave propagation. Failure of the specimens occurred on the lead side. This suggests that the lead - steel boundary is of higher strength than the pure lead, thus proving sufficient joint strength. The tensile strength of the initial lead used for cladding was determined to be $12.8 \mathrm{MPa}$.

The bend test is presented in Figure 4. Similar specimens to those used for the tensile test were machined from the fabricated bimetal. The specimen was firmly clamped in a vice and its free end was bent by $180^{\circ}$ around a mandrel of $\oslash 14 \mathrm{~mm}$ in diameter. The specimen was placed in such a manner that the notch face included a $30^{\circ}$ angle with the normal plane. The boundary was so strong that no damage occurred even when the mandrel diameter was reduced to $\oslash 8 \mathrm{~mm}$.

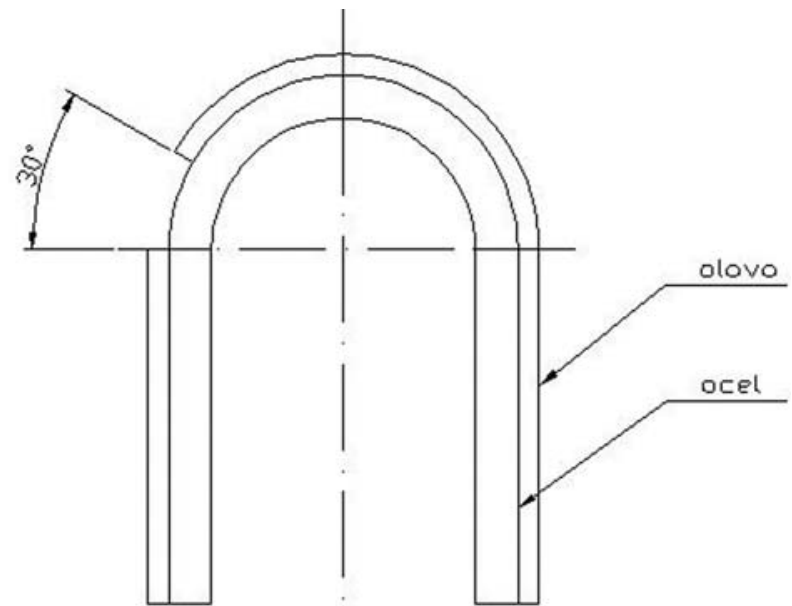

Figure 4: Scheme of the bend test of the bimetal 


\subsection{Metallographic assessment of the welded joints}

Observation by optical microscopy showed that the basic structure of the steel was polyhedral, locally deformed on the boundary. The thickness of the deformed layer was around $0.5 \mathrm{~mm}$. The measured wave amplitude was 0.08 to $0.1 \mathrm{~mm}$, and the waving period was 0.48 to $0.53 \mathrm{~mm}$. The weld boundary is shown in Figures 5 to 8.

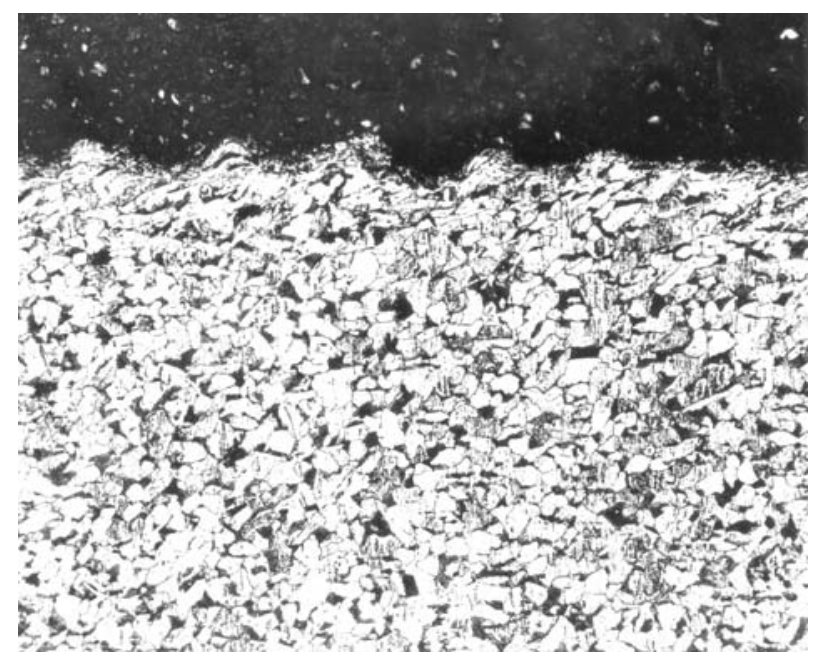

Figure 5: Weld boundary of the lead — steel bimetal $110 \times$

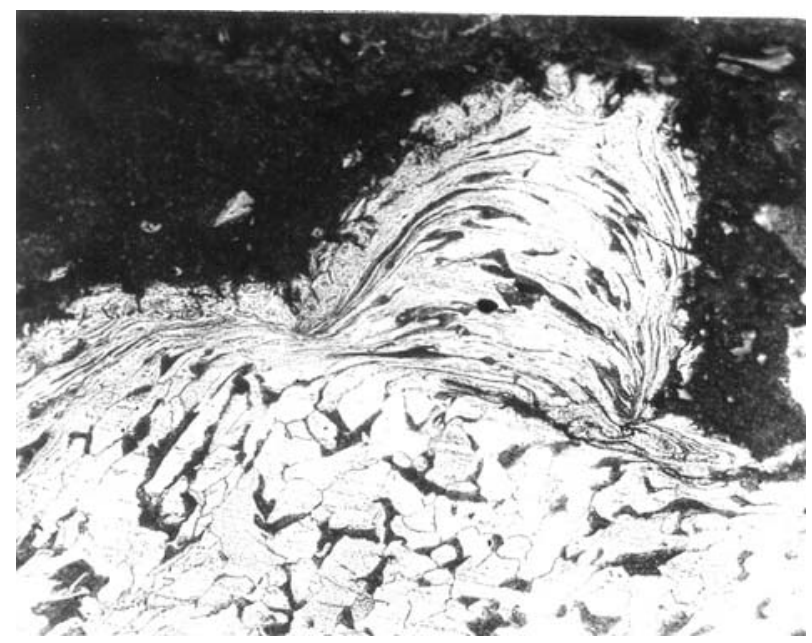

Figure 6: Weld boundary of the lead - steel bimetal $600 \times$

A more detailed assessment of the character of the fractured surfaces of a $\mathrm{Pb}$ - steel welded joint was performed by scanning electron microscope (SEM). The specimens from which the lead was torn off in the peel test were observed. It was observed that failure occurred after preliminary plastic strain, mostly by ductile fracture. Figures 7 and 8 show the ductile fractures in the lead which progressed to the darker zones where insufficient bonding of materials was observed. The bonding of $\mathrm{Pb}$ to the parent steel material was around $55 \%$.

Figures 7 and 8 show the fractures after fusing down of $\mathrm{Pb}$ from the steel surface in a vacuum.

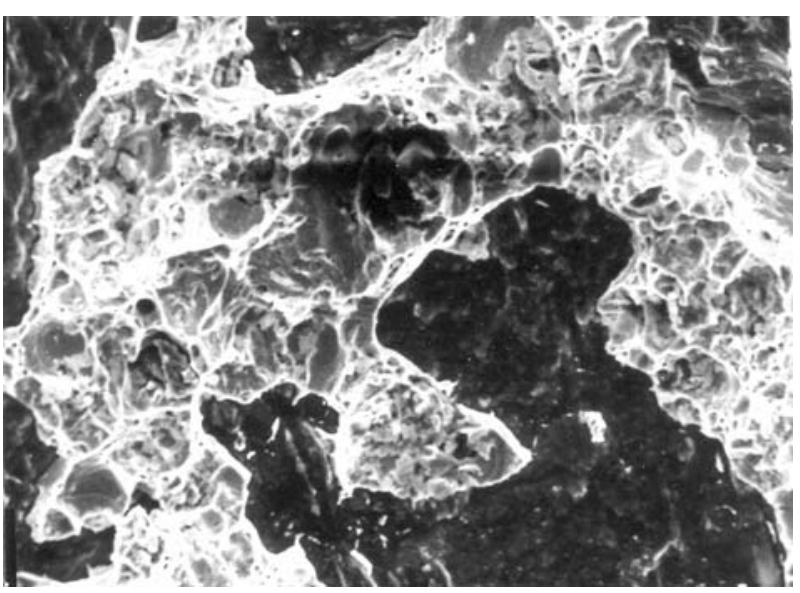

Figure 7: Ductile fracture in the lead (REM) $500 \times$

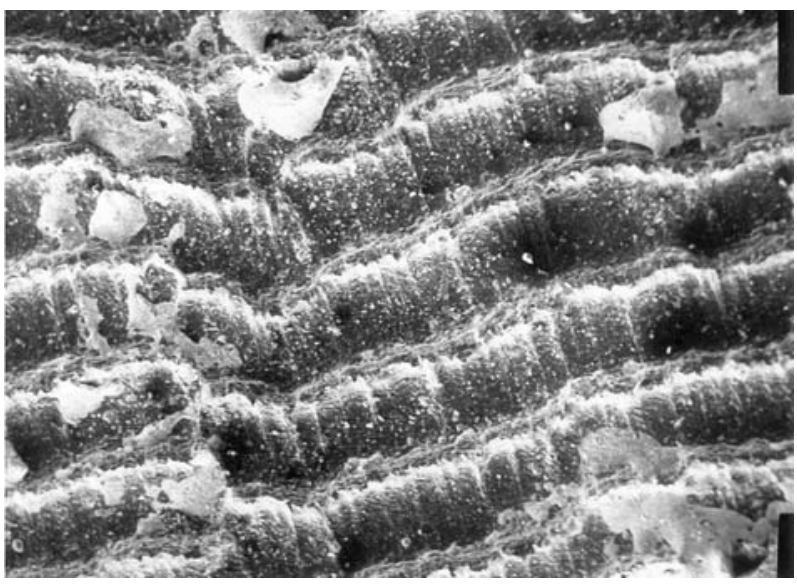

Figure 8: The lead fused from the steel surface $500 \times$

\section{Conclusions}

The aim of our study was to develop and test a special technology for lead cladding on a steel plate made of structural carbon steel. A total of 8 bimetallic welded joint swith dimensions of $120 \times 120 \times 14 \mathrm{~mm}$ were fabricated. On the basis of our results it can be stated:

Sound welded joints were fabricated by explosion cladding with optimum parameters. A new explosive was tested and it was found to be suitable for cladding the lead. Mechanical testing (a peel test, a shear test, and a bend test) of the bimetals proved their high quality. The failure of the specimens occurred on the lead side during the shear test. The boundary was so strong that no damage occurred 
even when the mandrel diameter was reduced to $\oslash 8 \mathrm{~mm}$ in the bend test. The peel test showed that the boundary remained undamaged and the punch penetrated through the lead.

On the basis of our experience and results it may be stated that this technology is promising one for fabricating bimetals. It is important to emphasize that the technology we have developed posseses no health hazards unlike the risky process of lead surfacing by flame.

\section{Acknowledgement}

This work was realised with support from GA VEGA MŠ VVŠ SR and SAV. Projects No. 1/2594/12.

\section{References}

[1] Turňa, M., Špeciálne metódy zvárania (Special welding methods). Bratislava : ALFA, 1989. ISBN 80-05-00097-9.
[2] Farba, L': Návrh technológie navárania olovom funkčných plôch chemických nádob. Bratislava : SjF SVŠT, 1985.

[3] Available on: http://www.explozia.cz

[4] Škorvánková, A.: Posúdenie vhodnosti navárania olova na ocel explóziou (Feasibility study of explosion cladding of lead on steel). Bratislava : $\mathrm{SjF}$ SVŠT, 1986.

[5] Turňa, M.: Zváranie kovov v pevnom stave (Solid state welding of metals). Lectures delivered at IWE, FS ČVUT Prague, 2010.

[6] Shane, A. H.: Welding Fume in the Workplace. Available on: http://www.aiha.org/localsections/ html/NTS/0602News1.pdf

[7] Gulbin, V. N., Krupin, A. V., Pashukov, Y. N., Yarutich, T. Y.: Examination and Development of Technology for Explosion Welding Lead Titanium Anodes. Welding International, 1996, Vol. 10, No. 8, p. 647-648. 